\title{
PEEK in dentistry, properties and application areas
}

\author{
Canan Akay1 ${ }^{\oplus}$, Miraç Berke Ersöz ${ }^{1}$ \\ ${ }^{1}$ Eskişehir Osmangazi University, Faculty of Dentistry, Department of Prosthodontics, Eskişehir, Turkey
}

\section{Correspondence:}

\section{Dr. Canan AKAY}

Eskișehir Osmangazi University, Faculty of Dentistry, Department of

Prosthodontics, Eskișehir, Turkey.

E-mail:cnngcr2@hotmail.com

Received: 16 September 2019

Accepted: 19 April 2020

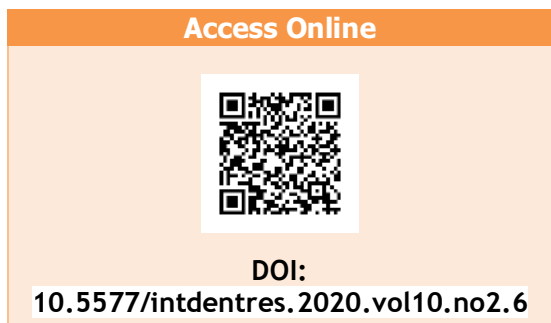

Keywords: PEEK (Polyetheretherketone), Prosthodontics, İmplant, Thermoplastics

How to cite this article: Akay C, Ersöz MB. PEEK in dentistry, properties and application areas. Int Dent Res 2020;10(2):60-65.

https://doi.org/10.5577/intdentres.2020.vol10.no2.6

\section{Introduction}

Polyetheretherketone (PEEK) is a polyaromatic compound which is a polyaryleterketone group (1). It is promising thanks to the appropriate physical and mechanical properties in the fields of medicine and dentistry.

There are many uses of PEEK: (2)

- maxillofacial and cranial implant,

- Spinal surgery,

- Orthopaedic surgery,

- A dental implant, root canal material carbon fiber reinforced PEEK(CFRPEEK),

- Cardiac surgery
The areas of use in dentistry are (3-5):

I. implants
a) implant
b) implant supported bar
c) abutment
d) temporary abutment
e) healing cap

II. fixed prostheses

III. endocrowns

IV. removable dentures

V. maxillofacial prostheses

VI. orthodontic wire

PEEK is synthesized by an alkylation reaction that combines 4'40- difluoro benzophenone with hydroquinone salt Fig. 1 (6). Ether bond gives the 
molecule an axial displacement, while the benzene ring gives stiffness.

The molecule has two microstructures: (6)

1. Crystalline phase

2. Amorphous phase (surrounds crystals)

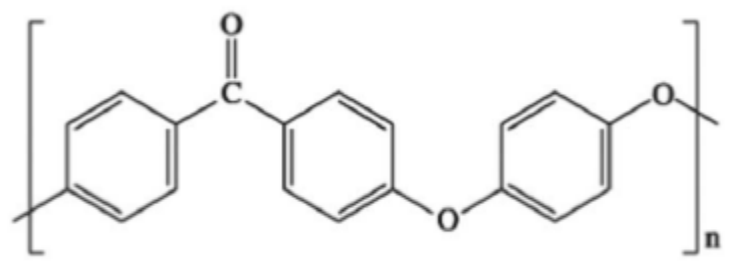

Figure 1. Chemical formula of PEEK

PEEK has a close modulus of elasticity to the bone (3-4GPa), it can be used as an alternative to metal implants $(7,8)$. PEEK is an inert material and it's thermal properties remain stable in the human body (2). According to Katzer et al, PEEK and CFRPEEK do not exhibit cytotoxic, mutagenic reaction (9). Similarly, PEEK does not show an allergic reaction according to the study of Wenz et al. (10). PEEK has high thermal degradation resistance, melting temperature is $334^{\circ} \mathrm{C}(2,11)$. It provides radiolucent imaging, so it is compatible with imaging techniques such as magnetic resonance imaging (MRI), computerized tomography (CT), and X-RAY (12). Combination with barium sulfate can increase the radioopacity (6). It has resistance to gamma radiation (2). One of the disadvantages is unable to osseointegration (13)(14). This restricts its use on the implant surface or biomedically (15). Another disadvantage is that the bond strength is low during the veneering process with the composite since the wettability is insufficient (16). In addition, PEEK may be appropriate for individuals with metal allergies (17). It can also be reinforced with carbon or glass fibers and modified with nanoparticles (18). Carbon fiber-reinforced PEEK turns into black (6). Reinforced PEEK provides a more aesthetic appearance due to its white color on the gingiva, which has a fine biotype (19).

Advantages of PEEK: $(6,9,20)$

1. Resistant to radiation,

2. Resistant to various chemicals,

3. Insoluble in solvents in the mouth and at room temperature,

4. Stable over $300^{\circ} \mathrm{C}$,

5. More durable than many metal restorations,

6. Can be reinforced with carbon fiber,

7. Tolerable in allergic patients,

8. Can be sterilized repeatedly without degradation
Disadvantages: $(6,21)$

- Lack of osseointegration,

- Low wettability,

- Not aesthetic due to metallic gray,

- Difficult to manufacture implants,

- Radiolucent imaging.

\section{PEEK with Fixed Prosthesis}

PEEK is a recommended material for fixed prostheses (16). PEEK has been modified by techniques such as mixing, filling, fiber reinforcement to obtain a material that is more rigid and suitable for dental use (12).

PEEK can be used in fixed prostheses because of its suitable mechanical properties thanks to inorganic chemicals in it (22). It can be produced by methods such as vacuum pressing, milling (Computer aided milling-computer aided manufacturing) (22). Also, PEEK is recommended as a framework material for a fixed dental prosthesis (23) due to its hardness (24). According to Lieberman et al. PEEK has low solubility and water absorption values when compared materials such as polymethylmethacrylate (PMMA) and can be considered for long term restorations (24).

PEEK is a white-gray non-aesthetic material and requires veneering for anterior use $(16,25)$.

Veneering methods are effective on fracture load. When digital veneering is performed, the fracture load is higher, regardless of the aging level (25).

Many studies have been done on strengthening the connection between PEEK and composite. Since conventional composite veneering applications were not sufficient for PEEK, different methods were applied. In studies with sulfuric acid and piranha solution, it has been observed that sulfuric acid increases the bond strength (16). Airborne-particle abrasion, etching and plasma treatment are known as methods to increase wettability (16).

According to the study by Uhrenbaher et al, airborne-particle abrasion ( $50 \mu \mathrm{m}$ alumina particles) and sulfuric acid etching (60 seconds) should be applied before bonding PEEK crowns. It was also concluded that retention was increased by the use of various bonding systems (Signum PEEK Bond, visio.link) (26).

According to the results on research conducted on the surface of PEEK, microwave supported coating technology can be used more quickly and reliably than conventional methods (15).

Load bearing capacity was evaluated in a laboratory study on a three-unit inlay retained bridge. The restorations with PEEK showed high loadbearing capacity and the fractures were mostly seen in the connector region (27).

Modified PEEK materials with ceramic fillers are preferred for temporary purposes in resin bonded fixed dental prosthesis(RBFDP) since they are more aesthetic in appearance compared to metal 
substructures (28). Similarly, veneered PEEK can be used as the interim framework of RBFDP in the anterior region as an alternative to materials such as metal-ceramic, glass infiltrated alumina, zirconia, and lithium disilicate (17).

\section{PEEK in Implants}

Implant treatment is one of the most accepted indications in terms of success and satisfaction in treating missing teeth in today's dentistry.

PEEK was used in spinal and hip surgeries at the beginning and can now be used as computer designed craniofacial implants $(29,30)$. It can be used in the reconstruction of facial deformities with interlocking systems in jaw and zygoma deformities (31). In addition, the data of a review study shows that there are many positive properties compared to titanium alloys (32).

PEEK is a promising material that can be used as an implant with its low elasticity modulus (Young's modulus) and easily modified and strengthened carbon fiber-reinforced PEEK (CFR-PEEK)(5) and glass fiber-reinforced PEEK(GFR-PEEK) (33).

Since the osseointegration of PEEK is limited, osteoblast activity is tried to be increased by various surface modifications (13) Surface properties and chemistry, increasing wettability are decisive for cell adhesion and proliferation (14). A number of studies have been carried out to improve the wettability of the material by changing the surface properties. Alumina-coated PEEK samples were examined by Akkan et al. with oxygen plasma etching and laser modification, according to the data obtained, wettability is increased for implantation (14). PEEK is coated with hydroxyapatite and promising results were obtained (21).

Plasma immersion ion implantation (PIII) technique can be applied by using water $-\mathrm{H} 2 \mathrm{O}$ and ammonia-NH3 to improve the bone interface properties of PEEK implants. With this application, effects on cell interaction, surface adhesion, proliferation, osteogenic differentiation have been increased (34).

CFR-PEEK, pure PEEK and titanium implants were compared using finite element analysis. In this study, stress, deformation, and contact pressures were investigated by applying force on these implant materials with $100 \mathrm{~N}$ parallel and $30^{\circ}$ angle from the buccal surface. Accordingly, CFR-PEEK implants achieved almost the same values as titanium, but more work was needed for pure PEEK (35).

The internal spline mechanism has been developed as an alternative to the hexagonal mechanism commonly used in the implant abutment interface. In order to measure the average insertion torque and the suitability for immediate loading, a $32 \mathrm{~N} \mathrm{~cm}$ torque was applied to titanium, PEEK and CFR-PEEK dental implants. Titanium implants were found to be more resistant in this study (36).

Several methods have been developed to alter the surface properties of PEEK to improve bioactivity (33).
The change in surface properties after sandblasting with aluminum oxide was investigated. Reinforced (CFR-PEEK) and filler (ceramic filled PEEK) were found to be suitable surface roughness for osseointegration after blasting (37). PEEK surface development processes are summarized in Table 1 (7).

According to Khonsari et al, although PEEK is a promising material in dentistry and implantology, there are cases with failure when used as an implant. Therefore, further research is needed (40).

Histological examinations revealed different tissue behavior and inflammatory cytokines around different implant materials. The level of DNA is less pronounced around PEEK implants, with alkaline phosphatase and osteocalcin levels are higher around Titanium-Aluminum-Vanadium alloys. However, IL1B, IL-6, IL-8 levels, which are proinflammatory cytokines, have been observed higher around PEEK implants and at least around $\mathrm{Ti}$ alloys. Antiinflammatory cytokine IL -10 level was higher in $\mathrm{Ti}$ alloys than PEEK. The cause of fibrosis tissue formation around PEEK implants can be attributed to the formation of these proinflammatory cytokines. However, Ti alloy surfaces provide a more favorable environment for osteogenic activity (41).

Various materials are used in as implant abutments, such as titanium, gold, zirconia, alumina, and glass. High-strength polymer materials such as PEEK are also recommended as abutments in many implant-supported restorations (18). Less bacterial biofilms are observed compared to titanium and zircon abutments. Research has shown that PEEK can be used as an immediate definitive abutment and framework material (18).

A study conducted by Kaleli et al. noted that the use of custom PEEK abutments increases stress and is not suitable for posterior use in individuals with parafunctional habits (42).

According to Neumann et al. when used as an abutment, PEEK exhibits lower fracture resistance than titanium alloys (43). It was concluded that reinforced PEEK abutments are a good alternative to titanium abutments in an animal study evaluating the effect of PEEK and titanium abutments on biological width and soft tissue stability (19). Similarly, in an animal study that examined the effect of pure PEEK, roughened PEEK, titanium bonded PEEK and titanium healing abutments on hard and soft tissue healing, it was concluded that PEEK healing abutments were an alternative to titanium (44).

In the all-on-four treatment protocol, PEEK framework can be used in the production of implantsupported fixed prostheses during the permanent loading. According to Zoidis, when PEEK is produced by veneering with PMMA, considering the aesthetic and biomechanical advantages of PEEK, it's been a good alternative to conventional ceramic and metalceramic prostheses (45).

In a study comparing tensile strength between PEEK and Titanium abutment screws, titanium screws were found to be significantly resistant. However, PEEK reinforced by $>50 \%$ continuous carbon fibers can be considered as abutment screw (46). 
In 10 patients with maxilla anterior defect, fixed acrylic restoration study was performed using PEEK and titanium subperiosteal implants. PEEK implants produced by CAD-CAM have positive results despite limited osseointegration properties (47).

Table 1. Surface treatment of PEEK

\begin{tabular}{|c|c|}
\hline Coating & $\begin{array}{l}\text { - } \quad \text { Plasma spraying- hydroxyapatite (21)/ titanium } \\
\text { - } \\
\text { - } \\
\text { - }\end{array}$ \\
\hline Surface topographical modification & $\begin{array}{l}\text { - } \quad \text { Acid etching -Sulfuric acid }(38,39) \text { - Piranha } \\
\text { acid(26) } \\
\text { - } \quad \text { Sandblasting - } \mathrm{TiO}_{2} \text {, Aluminum oxide (37) }\end{array}$ \\
\hline Chemical modifications & $\begin{array}{ll}\text { - } & \text { Sulphonation } \\
\text { - } & \text { Amination } \\
\text { - } & \text { Nitration }\end{array}$ \\
\hline Incorporating with bioactive properties & - Bioactive inorganic materials \\
\hline Improving hydrophilicity & $\begin{array}{ll}\text { - } & \text { UV irradiation } \\
\text { - } & \text { Plasma gas treatment }\end{array}$ \\
\hline
\end{tabular}

\section{PEEK with Removable Prosthesis}

In the indications of removable prostheses, intraoral examination, patient's expectations, and material selection are important. Removable partial dentures are supported by the mucosa or teeth. PMMA based acrylics are used as base material and $\mathrm{Cr}$-Co alloys are preferred for the framework. However, it causes aesthetic and allergic problems. Polyamides (deflex, valplast), developed for a solution, are produced by thermal injection, have more aesthetic and nonallergic compounds. Removable dentures should have rigid major connector components but polyamide materials show weakness (48-52). In addition, polyamides are less preferred because of their color instability, difficulty in repairing, bacterial and fungal colonization (51). However, acetal resins are also seen as flexible, aesthetic base and clasp material (53). In the study that investigating removable partial dentures' fit to tissue and teeth produced by PEEK, the gap between occlusal rest, major connector and denture base was measured. It was observed that PEEK RPDs produced by CAD-CAM technology was more compatible than conventional Cr-Co RPDs (54). Modified PEEK (BioHPP) is a material that can be an alternative to conventional RPDs considering the positive properties. Low plaque affinity, nonallergic, water insolubility, hygienic, easily relined, lower weights are advantages of modified PEEK. Also, it can be produced by CAD-CAM or conventional lost wax techniques (55). Also according to Arnold et al. by using CAD-CAM techniques RPD frameworks can be produced more compatible than the casting technique (56). In addition, vertical dimension arrangement can be made with temporary RPDs using digitally fabricated PEEK frameworks (57).

Another area may also be the construction of obturator prostheses. Due to the light weight of PEEK, it is possible to rehabilitate large oronasal defects (58).

\section{PEEK in Orthodontics and Pediatric Dentistry}

PEEK can be used in orthodontics and pediatric dentistry. It can be designed and applied as a space maintainer digitally. The aim here is to improve the quality of treatment. Also, PEEK is promising as an orthodontic appliance (59). For a solution of nonmetallic wire in orthodontics, PEEK arc wires have been developed. PEEK is considered as a nonmetal and aesthetic arc wire due to its properties such as high bending strength, creep resistance, similar orthodontic force to $\mathrm{Ni}$-Ti wire and low water absorption (60). In the PEEK tube method developed by Shirakawa et al, the metal arch wire was passed through the PEEK tube and acceptable aesthetic appearance was obtained (61). PEEK wires can be applied as an alternative to $\mathrm{Ni}$ - $\mathrm{Ti}$ (62).

\section{Conclusions}

PEEK is a highly durable polymer which has good mechanical and physical properties and has been used in many fields in recent years. With the introduction of PEEK in dentistry, progress has been made. PEEK used in prosthodontics as an implant 
material, abutment, fixed, removable partial prosthesis frameworks. Several studies have been conducted in vitro to increase the binding potency with resins. It is also accepted as an alternative to space maintainers and $\mathrm{Ni}$ - $\mathrm{Ti}$ wires in orthodontics. Based on its positive characteristics, PEEK is a promising material in dentistry and industry.

Peer-review: Externally peer-reviewed.

Author Contributions: Conception - C.A.; Design - C.A., M.B.E.; Supervision - C.A.; Materials - C.A.; Data Collection and/or Processing - C.A., M.B.E.; Analysis and/or Interpretation - M.B.E.; Literature Review - C.A., M.B.E.; Writer - C.A., M.B.E.; Critical Review - M.B.E.

Conflict of Interest: No conflict of interest was declared by the authors.

Financial Disclosure: The authors declared that this study has received no financial support.

\section{References}

1. Stawarczyk B, Beuer F, Wimmer T, Jahn D, Sener B, Roos M, et al. Polyetheretherketone - A suitable material for fixed dental prostheses? 2013;1209-16. (Crossref)

2. Tekin S, Adıgüzel Ö, Cangül S. An evaluation using micro-CT data of the stress formed in the crown and periodontal tissues from the use of PEEK post and PEEK crown: A 3D finite element analysis study. Int Dent Res 2018;8(3):144-50. (Crossref)

3. Nizam N, Gürlek Ö, Akcalı A. Estetik Bölgenin İmplantasyon Öncesi Sert ve Yumuşak Doku Ogmentasyonu ile Hazırlanması : Vaka Sunumu Implant Site Preparation with Hard and Soft Tissue Augmentation in Esthetic Zone: A Case Report. EÜ Dișhek. Fak. Derg. 2014;35(2):41-6. (Crossref)

4. Zoidis P, Bakiri E, Polyzois $G$. Using modified polyetheretherketone (PEEK) as an alternative material for endocrown restorations: A short-term clinical report. J Prosthet Dent [Internet]. 2017;117(3):335-9. (Crossref)

5. Bds SN, Bds MSZ, Bds ZK, Bds FS. Applications of polyetheretherketone ( PEEK ) in oral implantology and prosthodontics. J Prosthodont Res [Internet]. 2015;60(1):129. (Crossref)

6. Tekin S, Cangül S, Adıgüzel Ö, Değer Y. Areas for use of PEEK material in dentistry. Int Dent Res 2018;8(2):84-92. (Crossref)

7. Almasi D, lqbal N, Sadeghi M, Sudin I, Rafiq M, Kadir A, et al. Preparation Methods for Improving PEEK's Bioactivity for Orthopedic and Dental Application : A Review. International Journal of Biomaterials 2016;2016. (Crossref)

8. Schwitalla A, Mu W. PEEK Dental Implants: A Review of the Literature. J Oral Implantol. 2013;39(6):743-9. (Crossref)

9. Katzer A, Marquardt H, Westendorf J, Wening J V, Foerster $\mathrm{G}$ Von. Polyetheretherketone cytotoxicity and mutagenicity in vitro. Biomaterials. 2002;23:1749-59. (Crossref)

10. Wenz LM, Memitt K, Brown SA, Moet A. In vitro biocompatibility of polyetheretherketone and polysulfone composites. J. Biomed. Mater. Res. 1990;24:207-15. (Crossref)

11. Di P, Dal TA, Kocatepe A, Di P, Dal TA, Di P, et al. POLIETER ETER KETON (PEEK) ve DENTAL KULLANIMI “ POLYETER ETHER KETONE (PEEK)” AND ITS DENTAL USE.:1-14.
12. Stawarczyk B, Jordan P, Schmidlin PR, Roos M, Eichberger M, Gernet W, et al. PEEK surface treatment effects on tensile bond strength to veneering resins. J Prosthet Dent. 112(5):1278-88. (Crossref)

13. Zheng $Y$, Xiong $C$, Wang Z, Li X, Zhang L. A combination of CO 2 laser and plasma surface modification of poly ( etheretherketone ) to enhance osteoblast response. Appl Surf Sci. 2015;344:79-88. (Crossref)

14. Akkan CK, Hammadeh ME, May A, Park H, Abdul-khaliq H, Strunskus T, et al. Surface topography and wetting modifications of PEEK for implant applications. Lasers Med Sci 2014;1633-9. (Crossref)

15. Zhou H, Goel VK, Bhaduri SB. A fast route to modify biopolymer surface : A study on polyetheretherketone ( PEEK ). Mater Lett. 2014;125:96-8. (Crossref)

16. Stawarczyk B, Ing D, Cdt FH, Thrun H, Eichberger M. Effect of different surface pretreatments and adhesives on the load-bearing capacity of veneered 3-unit PEEK FDPs. J Prosthet Dent. 114(5):666-73. (Crossref)

17. Emera RMK, Altonbary GY. Retention force of zirconia bar retained implant overdenture: Clinical comparative study between PEEK and plastic clips. Int Dent Res 2019;9(3):92-8. (Crossref)

18. Al-Rabab'ah M, Hamadneh W, Alsalem I, Khraisat A, Karaky AA. Use of High Performance Polymers as Dental Implant Abutments and Frameworks: A Case Series Report. J Prosthodont. 2017;1-8. (Crossref)

19. Eduardo J, Sánchez M, Val D, Gómez-moreno G, Martínez CP, Ramírez-fernández MP, et al. Peri-implant tissue behavior around non-titanium material: Experimental study in dogs. Ann Anat. 2016;206:104-9. (Crossref)

20. Bakar A, Cheang P, Khor KA. Mechanical properties of injection molded hydroxyapatite-polyetheretherketone biocomposites. Manag Dyn Networks Organ Perspect Technol Enabled Inter-firm Collab. 2006;63:93-111.

21. Rabiei A, Sandukas S. Processing and evaluation of bioactive coatings on polymeric implants. J Biomed Mater Res Part A 2013;101(9):2621-9. (Crossref)

22. Stawarczyk B, Eichberger M, Uhrenbacher J, Wimmer T, Edelhoff D, Schmidlin PR. Three-unit reinforced polyetheretherketone composite FDPs: Influence of fabrication method on load-bearing capacity and failure types. Dent Mater J. 2015;34(1):7-12. (Crossref)

23. Heimer S, Schmidlin PR, Roos M, Stawarczyk B. Surface properties of polyetheretherketone after different laboratory and chairside polishing protocols. J Prosthet Dent. 2017;117(3): 419-25. (Crossref)

24. Liebermann A, Wimmer T, Schmidlin PR. Physicomechanical characterization of polyetheretherketone and current esthetic dental CAD / CAM polymers after aging in different storage media. J Prosthet Dent. 2016;115(3):321-8e2. (Crossref)

25. Taufall S, Eichberger M, Schmidlin PR, Stawarczyk B. Fracture load and failure types of different veneered polyetheretherketone fixed dental prostheses. J Prosthet Dent. 2016;20-2493-2500. (Crossref)

26. Uhrenbacher J, Schmidlin PR, Keul C, Eichberger M, Roos M, Gernet $W$, et al. The effect of surface modification on the retention strength of polyetheretherketone crowns adhesively bonded to dentin abutments. J Prosthet Dent. 2014;112(6): 1489-97. (Crossref)

27. Cekic-nagas I, Egilmez F, Ergun G, Vallittu PK. Load-bearing capacity of novel resin-based fixed dental prosthesis materials. Dent Mater J. 2018;37(1):49-58. (Crossref)

28. Andrikopoulou E, Zoidis P. Modified PEEK Resin Bonded Fixed Dental Prosthesis for aYoung Cleft Lip and Palate Patient. 2016;28(4):201-7. (Crossref)

29. Ng ZY, Nawaz I. Computer-Designed PEEK Implants: A Peek Into The Future of Cranioplasty? J Craniofac Surg. 2014;25(1):55-8. (Crossref) 
30. Rammos CK, Cayci C, Castro-Garcia JA, Feiz-Erfan I, Lettieri SC. Patient-Specific Polyetheretherketone Implants for Repair of Craniofacial Defects. J Craniofac Surg. 2015;26(3):631-3. (Crossref)

31. Thomas $M$, Interlocking NJL, Oral IJ. Interlocking polyetheretherketone implant. Int J Oral Maxillofac Surg [Internet]. 2016;45(8):969-70. (Crossref)

32. Wiesli MG, Özcan M. High-performance polymers and their potential application as medical and oral implant materials: A review. Implant Dent. 2015;24(4):448-57. (Crossref)

33. Rahmitasari F, Ishida $Y$, Kurahashi K, Matsuda $T$, Watanabe M, Ichikawa T. PEEK with Reinforced Materials and Modifications for Dental Implant Applications. Dent J. 2017;5(35):1-8. (Crossref)

34. Zhao Y, Wong HM, Lui SC, Chong EYW, Wu G, Zhao X, et al. Plasma Surface Functionalized Polyetheretherketone for Enhanced Osseo-Integration at Bone-Implant Interface. ACS Applied Materials \& Interfaces 2016;8(6):3901-11. (Crossref)

35. Schwitalla AD, Abou-emara M, Spintig T, Lackmann J, Müller WD. Finite element analysis of the biomechanical effects of PEEK dental implants on the peri-implant bone. J Biomech [Internet]. 2015;48(1):1-7. (Crossref)

36. Dominik A, Zimmermann $T$, Spintig $T$, Abou-emara $M$, Lackmann J, Müller W-D, et al. Maximum insertion torque of a novel implant-abutment-interface design for PEEK dental implants. J Mech Behav Biomed Mater [Internet]. 2018;77(September 2017):85-9. (Crossref)

37. Elawadly T, Radi IAW, Khadem A El, Osman RB. Can PEEK Be an Implant Material? Evaluation of Surface Topography and Wettability of Filled Versus Unfilled PEEK With Different Surface Roughness. J Oral Implantol. 2017;43:456-61. (Crossref)

38. Sproesser O, Schmidlin PR, Uhrenbacher J, Eichberger M, Roos M, Stawarczyk B. Work of adhesion between resin composite cements and PEEK as a function of etching duration with sulfuric acid and its correlation with bond strength values. Int J Adhes Adhes [Internet]. 2014;54:18490. (Crossref)

39. Zhou L, Qian Y, Zhu Y, Liu H, Gan K, Guo J. The effect of different surface treatments on the bond strength of PEEK composite materials. Dent Mater [Internet]. 2014;30(8):e209-15. (Crossref)

40. Khonsari RH, Berthier P, Rouillon T, Perrin J, Corre P. Severe infectious complications after PEEK-derived implant placement: Report of three cases. Asian J Oral Maxillofac Surg [Internet]. 2014;26(4):477-82. (Crossref)

41. Olivares-Navarrete R, Hyzy SL, Slosar PJ, Schneider JM, Schwartz Z, Boyan BD. Implant Materials Generate Different Peri-implant Inflammatory Factors. Spine Epidemiol. 2015;40(6):399-404. (Crossref)

42. Kaleli N, Sarac D, Külünk S, Öztürk Ö. Effect of different restorative crown and customized abutment materials on stress distribution in single implants and peripheral bone: A three-dimensional finite element analysis study. J Prosthet Dent [Internet]. 2018;119(3):437-45. (Crossref)

43. Fleck EA. Fracture resistance of abutment screws made of titanium, polyetheretherketone, and carbon fiberreinforced polyetheretherketone. 2014;28(1):1-5. (Crossref)

44. Rea M, Lang NP. Marginal healing using Polyetheretherketone as healing abutments: an experimental study in dogs. 2016;(Steinemann 1998):46-50. (Crossref)

45. Zoidis P. The all-on-4 modified polyetheretherketone treatment approach: A clinical report. J Prosthet Dent [Internet]. 119(4):516-21. (Crossref)
46. Schwitalla $A D$, Abou-emara $M$, Zimmermann $T$, Spintig $T$, Beuer F, Lackmann J, et al. The applicability of PEEK-based abutment screws. J Mech Behav Biomed Mater [Internet]. 2016;63:244-51. (Crossref)

47. Mounir M, Atef M, Abou-Elfetouh A, Hakam MM. Titanium and polyether ether sub-periosteal implants: two novel approaches for rehabilitation of the severely atrophic anterior maxillary ridge. Int J Oral Maxillofac Surg [Internet]. 2018;47(5):658-64. (Crossref)

48. 48. Soygun K, Demir H, Bolayir G, Demir AK. Esneyeblr Br Protez Kade Rezn Le Hareketl Bölümlü Protezlern Yapimi: Vaka Sunumu. Cumhur Üniversitesi Di? Hekim Fakültesi Derg. 2009;12(1):52-5.

49. 49. Yeșil Duymuș Z, Holoğlu B, Alkurt M. Poliamid yapıdaki protez kaide materyali ile hareketli bölümlü protez yapımı: iki vaka sunumu. Atatürk Üniv Diș Hek Fak Derg. 2011;18590.

50. Gözneli R, Akatay ZL, Kulak Ozkan Y. Esneyebilir hareketli bölümlü protezler. Türk Diș Hekim Derg. 2012;85:119-23.

51. Vojdani M, Giti R. Polyamide as a Denture Base Material: A Literature Review. J Dent Shiraz Univ Med Sci J Dent Shiraz Univ Med Sci. 2015;16(161):1-9.

52. Ucar Y, Akova T, Aysan I. Mechanical Properties of Polyamide Versus Different PMMA Denture Base Materials. J Prosthodont. 2012;21(3):173-6. (Crossref)

53. Lekha K, Roseline M, Savitha N, Nadiger R. Acetal resin as an esthetic clasp material. J Interdiscip Dent. 2012;2(1):11. (Crossref)

54. Ye $H$, Wang $G$, Kang J, Liu $Y$, Sun $Y$, Zhou $Y$. A novel computer-aided design/ computer assisted manufacture method for one-piece removable partial denture and evaluation of fit. 2018;31(2):149-51. (Crossref)

55. Zoidis P, Papathanasiou I, Polyzois G. The Use of a Modified Poly-Ether-Ether-Ketone ( PEEK) as an Alternative Framework Material for Removable Dental Prostheses . A Clinical Report. 2016;25:580-4. (Crossref)

56. Arnold C, Hey J, Schweyen R, Setz JM. Accuracy of CAD-CAMfabricated removable partial dentures. J Prosthet Dent [Internet]. 2018;119(4):586-92. Available from: https: //doi.org/10.1016/j.prosdent.2017.04.017 (Crossref)

57. Hahnel S, Scherl C, Rosentritt M, Fh PD. Interim rehabilitation of occlusal vertical dimension using a doublecrown-retained removable dental prosthesis with polyetheretherketone framework. J Prosthet Dent [Internet]. 119(3):315-8. (Crossref)

58. Costa-palau S, Torrents-nicolas J, Barberà MB, Cabratosatermes $\mathrm{J}$. Use of polyetheretherketone in the fabrication of a maxillary obturator prosthesis: A clinical report. J Prosthet Dent [Internet]. 2014;112(3):680-2. (Crossref)

59. lerardo G, Luzzi V, Lesti M, Vozza I, Brugnoletti O, Polimeni A, et al. Peek polymer in orthodontics: A pilot study on children. J Clin Exp Dent. 2017;9(10):e1271-5. (Crossref)

60. Maekawa M, Kanno Z, Wada T, Hongo T, Doi H, Hanawa T, et al. Mechanical properties of orthodontic wires made of super engineering plastic. Dent Mater J [Internet]. 2015;34(1):1149. (Crossref)

61. Shirakawa N, Iwata T, Miyake S, Otuka T, Koizumi S, Kawata T. Mechanical properties of orthodontic wires covered with a polyether ether ketone tube. Angle Orthod. 2018;88(4):442-9. (Crossref)

62. Tada Y, Hayakawa T, Nakamura Y. Load-deflection and friction properties of PEEK wires as alternative orthodontic wires. Materials (Basel). 2017;10(8):1-12. (Crossref) 